\title{
Uma Orquestra Sinfônica para São Paulo
}

Flávia Camargo Toni

A primeira orquestra sinfônica estável da cidade de São Paulo surgiu com a fundação do Departamento de Cultura - atual Secretaria Municipal de Cultura - na Direção de Mário de Andrade. Como a maioria das realizações da gestão do grande intelectual paulista (1935-1938), a criação da orquestra vinha responder a uma inquietação antiga do crítico e professor de música, ouvinte assíduo de nossas salas de concertos.

Na condição de espectador, Mário acompanhava o desfile anual de artistas e companhias de teatro estrangeiros trazidos por empresários ou pela Sociedade de Cultura Artística. Os instrumentistas de cordas e cantores, pouco afeitos a experimentarem os pianistas "da terra", geralmente traziam seus próprios acompanhantes. Mas as empresas que se encarregavam da organização das temporadas líricas, quando não conseguiam a verba suficiente para toda a "trouppe", trabalhavam com uma orquestra provisória, montada para a execução das óperas de cada estação. Quanto ao repertório sinfônico, ele praticamente inexistia durante o ano nos teatros paulistanos.

Para a arregimentação dos músicos havia, inclusive, uma espécie de firma, o Centro Musical de São Paulo, organizada por alguns integrantes da Sociedade de Concertos Sinfônicos. Com sede própria, à Rua da Quitanda, $n^{\circ} 6$, elencava, na propaganda, a vasta gama de sua prestação de serviços: "além das grandes orchestras de que dispõe para Theatro, organisa pequenos conjunctos orchestraes, para festas, casamentos, baptisados dispondo também 
de excellentes Jazz-Bands"]. Eventualmente, a Orquestra do Centro Musical de São Paulo apresentava-se em concertos, como aquele regido por Villa-Lobos a 2 de outubro de 1929, promoção da Sociedade de Cultura Artística.

No final da década de 20, além dessas duas orquestras - a da Sociedade de Concertos Sinfônicos e a do Centro Musical de São Paulo - que contavam com os mesmos integrantes, havia uma terceira, a mais antiga, que se apresentava de quando em quando. A Philharmonia, "Associação de Amadores fundada em julho de 1920", dirigida por Napoleão Vincent, tinha Diretoria, Comissão de Contas e até Comissão de Sindicância. Apresentava-se realmente pouco, uma vez que, a 6 de fevereiro de 1931, já com onze anos de existência, deu seu $60^{\circ}$ concerto.

Mas foi com a orquestra da Sociedade Sinfônica de São Paulo, criada em 1930 e de vida efêmera, que Mário de Andrade, então repórter do Diário Nacional, vivenciou as dificuldades da manutenção de um conjunto de tal porte, experiência que se revelou importante quando esteve à frente do Departamento de Cultura, seis anos depois. Além do mais, as histórias dos grupos da Sociedade Sinfônica de São Paulo e da Sociedade de Concertos Sinfônicos e suas respectivas diretorias transcorreram durante um momento especialmente turbulento da vida brasileira, entre 1929 e 1932, momento este acompanhado pelo jornalista que levava ao leitor o dia-a-dia dos bastidores da música da cidade.

Do longo período de atividade do crítico musical destacamse, grosso modo, em música, três momentos: o do Diário Nacional, entre agosto de 1927 e setembro de 1932, o do Diário de S. Paulo, de 1933 a 1935 e o da Folha da Manhã, de 1943 a 1945. Dos três, o momento menos conhecido é o primeiro, o que comporta os mais de 400 artigos escritos para as colunas "Música" e "Quartas Musicais". Escrever para o Diário Nacional, órgão oficial do Partido Democrático, fortalecia, no intelectual, o observador severo dos hábitos do público, conjuntos e empresários. Assim, aparentemente, os leitores perceberam nele um escritor em sintonia 
com a linha de trabalho do periódico e a 14 de junho de 1928 , talvez a pretexto de responder uma carta, ele explicou:

"Muita gente, pondo reparo em que o Diário Nacional está seriamente empenhado em moralizar a manifestação artística em São Paulo, me tem escrito mostrando falhas e defeitos pra que eu os acuse publicamente.(...)"2

E, de fato, expondo não só as dificuldades das orquestras, mas, principalmente, a conduta das Sociedades que as mantinham em relação ao que se convencionou chamar hoje em dia de "política cultural", seus escritos ultrapassavam os limites das críticas musicais de praxe. Assim, quando da publicação de Mísica, doce Música, ele mesmo selecionou algumas delas para as séries "Música de Pancadaria" ("Luta pelo Sinfonismo", 14 artigos, e "P.R.A.E", 5 artigos), e "Música de Coração" ("Villa Lobos versus Villa Lobos", 7 artigos). Escritas entre 1930 e 1931, destacam o papel do estudioso na análise dos repertórios, o defensor da classe musical lutando pela estabilidade dos grupos e sociedades de concertos e o formador de um público paulistano, aspectos intimamente relacionados pois, a formação de um gosto musical implica a formação de grupos estáveis com repertórios de qualidade e vice-versa. E uma vez que o autor escolheu as críticas que fez imprimir sem respeitar a cronologia completa de sua produção, foi necessário complementar certos "claros" naquelas séries com textos não publicados em livros, presentes, porém, no Arquivo do Instituto de Estudos Brasileiros da Universidade de São Paulo. Só assim foi possível reconstituir as histórias das duas orquestras implicadas em "Luta pelo Sinfonismo".

Como repórter do Diário Nacional, foi dito, Mário de Andrade acompanhava a vida da música da cidade protagonizada por artistas estrangeiros empresariados em grupo - nas temporadas líricas ou individualmente. O repertório apresentava poucas novidades, pois, público mal formado, esperava-se ouvir sempre obras conhecidas, a garantia de platéias lotadas. $O$ diletante amador presente em nossas salas de espetáculos, avesso às novidades de programa, foi satirizado em "Dona Eulália", terceira das cinco crônicas de 
estréia no Diário, publicada a 30 de dezembro de 1927, série "A Arte em São Paulo". O crítico supostamente assistiu a um concerto do Quarteto Paulista do Conservatório Dramático e Musical de São Paulo e, vale esclarecer, não localizei nenhum programa do conjunto em questão em dias próximos à apresentação aludida. Tal "audição", mote para falar de Dona Eulália, das programações das salas de concertos e do gosto do público paulistano, era dedicada às obras de Lorenzo Fernandez, o que obrigava os membros do conjunto a se mexerem "um pouco mais para arranjarem público" distribuindo, inclusive, ingressos grátis. A espectadora, curioso personagem tecido com habilidade pelo escritor, desaprovou o concerto tanto quanto o jornalista se empolgou com as peças do compositor carioca. Dona Eulália vivera dez anos em Paris e se autocredenciava ouvinte exemplar. Achou um jeito de repreender o entusiasmo do cronista dizendo, entre outras coisas, que nunca escutara "uma vergonheira dessas. Os artistas de Paris não vão tocar em concertos essas cantigas de caipiras! Só a música é nobre! Música de caipira a gente deixa para os caipiras. Indecente! (...) O senhor carece de ir para Paris ouvir música boa! Depois então o senhor não há de mais aplaudir essas bobagens de cidade sem civilização!... Música é Chopin, moço, é Liszt! Isso que é música!". Mulher que se dizia tão refinada, praticava o mecenato em casa promovendo, às quartas-feiras, um "chá grátis" com um "grupinho de pianistas deserdados e um violinista de boa canhota", elemento acrescentado ao perfil de Eulália para lembrar que o Quarteto Paulista, como outros grupos musicais, dependia, para seu sustento, da renda das bilheterias, pois a contribuição anual dos sócios era insuficiente.

E, assim como se empenhava na manutenção dos pequenos grupos musicais, amadores ou não, o crítico se verá envolvido, a partir de 1930, nas disputas da Sociedade de Concertos Sinfônicos e da Sociedade Sinfônica de São Paulo, cujas orquestras lutavam para sobreviver. Mário de Andrade sairá em defesa daquela que lhe parecia descompromissada com a política vigente uma vez que, por falta de bons profissionais, só uma delas poderia vir a apresen- 
tar repertórios de qualidade. A atitude, parcial, não significava, contudo, a desconsideração pela música amadora como se percebe, por exemplo, na crítica para o concerto da Filarmonia, o conjunto regido por Napoleão Vincent. Dividido entre dois espetáculos, pois, na mesma noite acontecia a apresentação do Quarteto Brasil, queixou-se da falta de organização de uma agenda de espetáculos para a metrópole mas disse ter conseguido ouvir, de cada grupo, o que mais lhe interessava musicalmente. Da orquestra queria escutar A beira do regato, de A. Levy e dois trechos da Suite Infantil de C. Guarnieri. Embora não tenha elogiado a interpretação, qualificou a Filarmonia como "uma das sociedades mais simpáticas de S. Paulo. Não só pela extraordinária durabilidade que tem, fundada em 1920, como por ser composta de amadores." Adiante, de forma construtiva, sugeriu: "E também, pelo seu cunho amadorístico, que a põe a salvo de exigências cegas de crítico, a Sociedade, já proficientemente dirigida pelo prof. Vincent, podia abrir as suas audições à direção dos compositores moços, de forma a thes permitir ocasião de treino que as outras duas sociedades sinfônicas, pelas suas próprias condições não amadorísticas não permitem. Assim a Filarmonia, já útil pelo que reúne e pelo fenômeno social admirável que representa, se tornaria utilíssima como escola de nossos futuros regentes."

O intelectual estava animado porque, fato inédito, São Paulo lutava pela manutenção de três orquestras, futuro promissor para uma capital que, meses antes, beirava a indigência musical. Pelo menos, este fora o diagnóstico do escritor em janeiro de 1930 ao declarar:

"O quadro verdadeiro da situação musical paulista é tão horroroso que só pode causar vergonha." Logo, porém, se entusiasmou ao saber que um grupo de jovens pretendia fundar "uma sociedade musical que estabeleça de fato uma tentativa de cultura musical (...)". Nascia a Sociedade Sinfônica de São Paulo.

A "esperança" que inspirou o título do artigo residia no fato de tal sociedade estar sendo pensada por moços: "Isso prova que já existe pelo menos em alguns, um sentimento íntimo que lhes diz 
que tudo está errado como vai, que carecem sair do obscurantismo musical inconfessável em que jazem."

Ao concluir, frisou que tal empresa só seria bem sucedida sem músicos de orquestra na diretoria, evitando-se, assim, os erros de sociedades anteriores, "viciadas", fazendo concessões a repertórios e regentes, com programas "de público fácil", "gênero Arlesiana, gênero Peer Gynt, gênero Tchaikowsky e Saint Saens, que faz o público gemer de gozo e ir pra casa sonhador. O curioso é que essas sociedades inda não repararam que elas não são feitas pelo público, e sim este é que é feito por elas." Explicou, então, que a "bronca" não valia só para a Sociedade de Concertos Sinfônicos, mas para todas aquelas que se formavam.

Ao que parece, a opinião do jornalista foi aceita pela Sociedade nascente já que, no Capítulo II, Artigo $6^{\circ}$, parágrafo $1^{\circ}$ dos estatutos da SSSP constava que maestro e músicos seriam considerados sócios, teriam direito a um ingresso por concerto, não pagariam mensalidades, mas, em compensação, não poderiam "votar nem ser votados nas assembléias gerais." Tudo justificava o nobre propósito da Sociedade de "organizar uma orquestra permanente para execução de obras sinfônicas de todas as épocas e escolas, e, especialmente, de autores nacionais."

A Diretoria da SSSP contava com nomes respeitados pela sociedade tendo Nestor Rangel Pestana por presidente honorário, Olívia Guedes Penteado - Presidente, Antonieta Penteado - Vicepresidente, $1^{\circ}$ secretário - Mina Klabin Warschavchik, $2^{\circ}$ secr. Marcelo da Silva Telles e Tesoureiro - Giuseppe Giacompol. O Diretor Artístico, Lamberto Baldi, egresso da Sociedade de Concertos Sinfônicos, além de regente era quem escolhia os programas ouvindo, porém, o Conselho Consultivo.

O Estatuto da SSSP também fazia saber que tal Conselho era composto de " 5 musicistas ou musicólogos de notória competência e reconhecida probidade, nomeados pela Diretoria", aos quais ela poderia "recorrer para esclarecimento e solução de questões de natureza artística." Dele faziam parte Furio Franceschini, Agostino Cantu, Félix de Otero e Francisco Casabona, além de Mário de 
Andrade. A tal Conselho cabia colaborar com Lamberto Baldi "na organização dos programas e na solução das questões de caráter técnico e artístico que lhe forem por ele submetidas", deliberações tomadas por maioria de votos e com o caráter de parecer, ou seja, cabia à Diretoria a decisão final.

O crítico não escondeu de seus leitores nem o fato de pertencer ao Conselho, nem sua animação com o surgimento da orquestra: "A diversidade de orientações das pessoas que formam esse conjunto, indica já o perfeito critério de unidade musical, destendenciosa, que orientará a agremiação nova. (...)".

E, de fato, a Sociedade foi fiel a seus propósitos: em doze de seus catorze espetáculos houve primeiras audições paulistanas ou brasileiras de compositores como Manuel de Falla (El sombrero de Tres Picos), Debussy (L'après midi d'un faune), Strawinsky (Fogos de Artifício), J. S. Bach (Terceiro Concerto Brandenburguês) ou Respighi (Festas romanas) - para citar só nomes expoentes sendo que, em dez, compareceram autores nacionais como $\mathrm{H}$. Oswald (Paisagem de Outono), Nepomuceno (Série Brasileira) ou A. Pereira (Cantos populares brasileiros).

Um olhar pouco mais detido nos programas que Mário manteve consigo pode revelar traços de proximidade entre ele e a SSSP que superam os da relação de mero aconselhamento: há dados curiosos sobre o ouvinte assíduo, bem como elementos que esclarecem parte da vida e da constituição do grupo. O crítico usava os exemplares guardados em seu escritório para, por exemplo, marcar lembretes. Só não esteve no $5^{\circ}$ concerto, de 28 de junho de 1930, anotando: "Não assisti. Estava em férias na roça". Embora presente no $11^{\circ}$, de 30 de abril de 1931, nada publicou a respeito. Desabafando, escreveu no impresso: "Não fiz crítica. O Diário Nacional estava suspenso por ordem dos indecentes Miguel Costa e João Alberto." E a intimidade entre o conselheiro e a Sociedade era tão grande que ele fez publicar, no programa distribuído ao público do dia 10 de junho de 1931, artigo em homenagem a José Antônio Ferreira Prestes, amigo e companheiro de oficio na crítica musical, o mesmo da coluna no Diário Nacional ${ }^{3}$. 
A dificuldade financeira da SSSP pode ser observada no conjunto dos livretos e confirmada nos textos de Mário de Andrade para o jornal. Se, por exemplo, os primeiros impressos traziam a relação dos componentes da orquestra, tais páginas foram aos poucos cedendo espaço para a propaganda de lojas finas e profissionais de vária arte. Ou seja, o espaço foi sendo redesenhado para acolher mais anunciantes à medida que a Sociedade necessitou de dinheiro. E a partir do $9^{\circ}$ concerto, o quadro com os nomes dos músicos, desta vez em uma só página, reapareceu trazendo, no verso, um "Indicador Profissional": faixas de um centímetro de altura, ocupando toda a largura da folha, eram vendidas aos professores de canto e de instrumentos que podiam anunciar, de forma econômica, suas especialidades e endereços. As faixas que não eram vendidas traziam a indicação impressa de "(Espaço disponível)". E foi justamente nos "espaços disponíveis" do "Indicador Profissional" da décima audição, a de 20 de março de 1931, onde ele escreveu, letra esmerada a tinta preta, os nomes de "Armando Belardi", "Giuseppe Manfredini", "Danton Vampré", "Agostino Cantu", "Raymundo de Macedo", "Torquato Amore", "Villa Lobos" e "Walter Mocchi". A ironia é flagrante, pois, à exceção de Agostino Cantu, os demais nomes vinham sendo combatidos pelo repórter em suas colunas no Diário Nacional após a Revolução de 30.

Com exceção de uma, as "Notas Explicativas" que acompanhavam os programas não eram assinadas. Mas quem, naquele momento, entre os estudiosos de música que compõem a Sociedade, aportuguesaria os nomes de Richard Strauss, Claude Debussy ou o título do poema sinfônico de Rimsky-Korsakow, Sherazade, para Xerazada? Veja-se, justamente, a conclusão da nota para a peça do compositor russo:

"E a obra termina, ampla, sossegada, num bem estar de sedas luxuosas. Dorme o Sultão Xariar, as histórias pararam em meio e a esperta Xerazada ganhou a vida por mais um dia." $\left(2^{\circ}\right.$ concerto da SSSP, 4 de abril de 1930)

A única nota com identificação de autor, Música, por Mina Klabin Warchavchik, no livreto do $10^{\circ}$ concerto, em tudo se apro- 
xima ao início do artigo de Mário publicado no ano anterior, aquele onde saudara a criação da SSSP. ${ }^{4}$ Mina respondia interinamente pela Diretoria da Sociedade e queria, como o critico, chamar a atenção para a importância da manutenção de uma orquestra. Em 1930 o jornalista historiara brevemente os conjuntos formados no Brasil a partir de 1584 lamentando os "inúmeros agrupamentos musicais, sem permanência, organizados as mais das vezes pra comemoração duma data (...)". Mesmo considerando que a orquestra fosse "o instrumento musical mais dispendioso" mencionou, como no texto de D. Mina Warchavchik, a vida sinfônica da América do Norte e Europa que, financeiramente, viviam "sempre numa atrapalhação danada".

Aliás, nas críticas que acompanharam os espetáculos da SSSP que pude recuperar, a tônica recai ora sobre a importância da manutenção de um grupo de tal porte na cidade, ora sobre a excelência das apresentações. Vivendo do patronato, mensalidades de sócios e vendas de bilhetes, a sinfônica vivia sob constante ameaça de falência. A matéria sobre o $4^{\circ}$ concerto, no entanto, aponta outro aspecto do jornalista que aproveitava as ocasiões propícias para sugerir melhoras e incrementar o trabalho em foco. Se elogiou maestro e músicos "que se sujeitaram a grandes sacrificios de treino pra nos apresentar a magnífica execução (...)" e chegou a qualificá-la como “(...) o exemplo mais admirável de arte sinfônica que já tivemos em S. Paulo.", ressalvou - ainda que veladamente - a primeira audição do $3^{\circ}$ Brandenburguês de Bach. Indignado com a falta de um cravo porque as empresas que alugavam pianos não dispunham do instrumento, lastimou a limitação do repertório que isto impunha, categórico: "Apareça o cravo que garanto aparecem cravistas." ${ }^{\prime 5}$ Adiante-se que o primeiro piano de concerto do Teatro Municipal de São Paulo foi adquirido só em 1936 pelo Departamento de Cultura, gestão de Mário de Andrade.

No segundo semestre de 1930, ou melhor, a partir da sexta audição, a jovem Sociedade Sinfônica seria abalada de forma inesperada durante a série dirigida por Villa-Lobos na capital. A série, com música de câmara e sinfônica, não contemplava apenas peças 


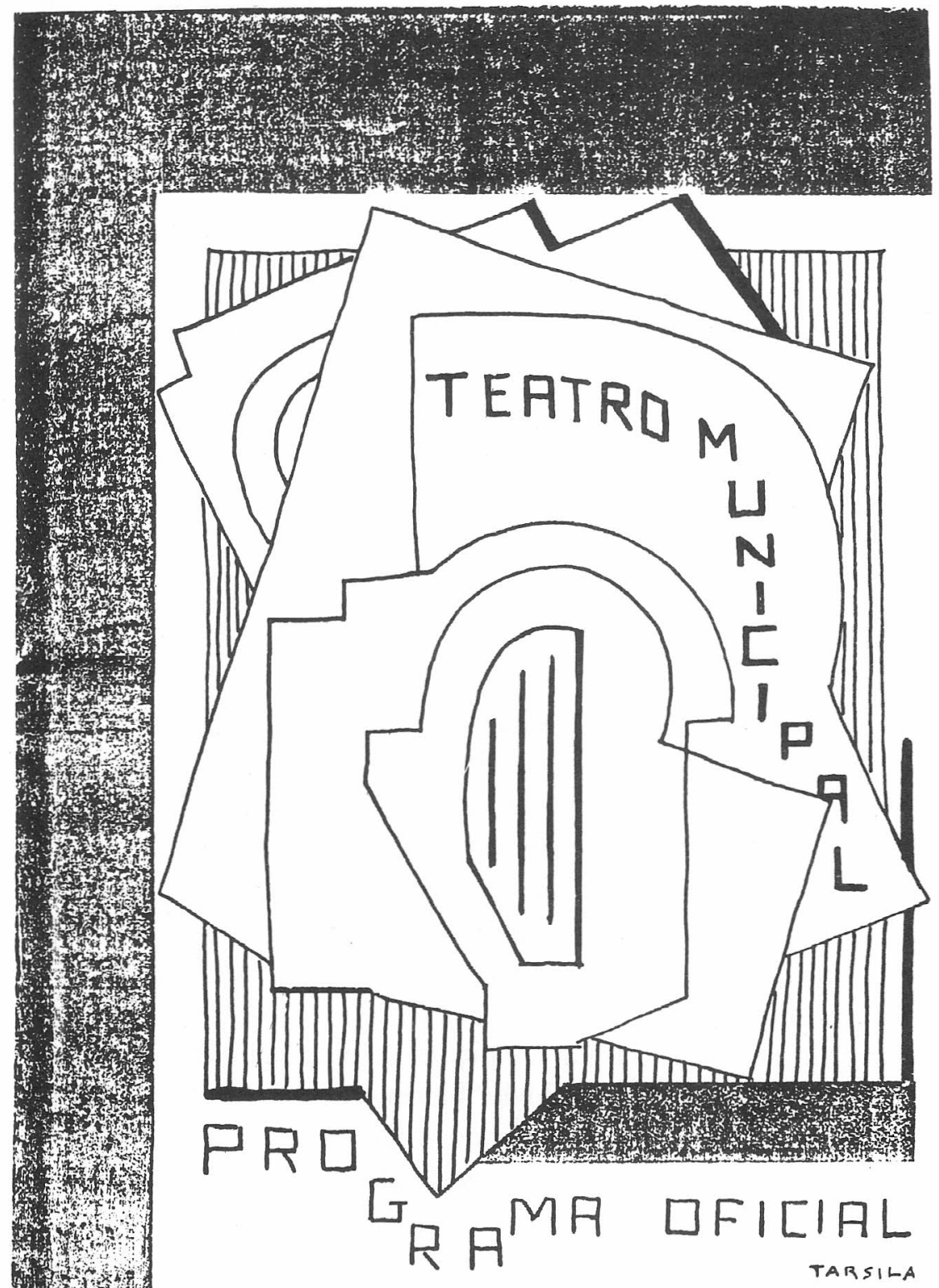

Capa de programa do Departamento de Cultura ilustrada por Tarsila Amaral (moldura na cor salmão, traços $\mathrm{em}$ preto sobre fundo branco). (Serke P'rogramas Musicais Brasileiros, Arq. Mário de Andrade, IEB-USP) 
do compositor carioca e contou, dentre as oito apresentações, com três participações da orquestra. O maestro teve dificuldades no lidar com os músicos, os "professores de orquestra", como os chamava Mário de Andrade, a ponto de tais querelas merecerem reprovações em letra de forma. O próprio Mário, no início condescendente com o amigo, acreditando que o conjunto não estava à altura de sua capacidade, mudou pouco a pouco de opinião. Assim, a 28 de julho, o jornalista aplaudiu a regência de Honegger, Coppola, Guarnieri e Cools, concebida de forma pessoal, sem os virtuosismos da profissão. Reprovou, no entanto, o comportamento de certos elementos do conjunto, manejados por intrigas, justificando: "Na concepção que Vila Lobos tem de interpretação sinfônica, o que o prejudica em S. Paulo é a própria constituição ainda atual das nossas orquestras. Na Europa a direção dele tem sido sempre eficiente porque as orquestras de lá são mecanismos já tradicionalizados e maleáveis que podem seguir perfeitamente as intenções dele. (...)" 6

Mas a reprovação do escritor - que, aliás, acabara de se desligar do Conselho Consultivo da SSSP - se faz notar na crítica para o dia 26 de agosto, qualificando de "complacência honrosa" o fato de várias associações possibilitarem a realização da temporada "famigerada" e que causava "mal-estar divertido" no meio musical paulista. Entre outros aspectos, desagradou-lhe a noite dedicada exclusivamente à obra de Florent Schmidt, uma "ingenuidade" de programação numa cidade onde há "tão pouca música". Além disso o grupo ainda não tinha condições técnicas de executar certos trechos. Embora qualificando de "benemerência" a participação da SSSP, Mário de Andrade lastimou o fato de alguns membros da própria sociedade terem se rido do fracasso do concerto. ${ }^{7}$

Mas a última apresentação de Villa-Lobos à frente da orquestra da SSSP mereceu três colunas do Diário Nacional. As duas primeiras, de 25 e 26 de setembro, foram dedicadas à análise de Amazonas; a avaliação da temporada, como um todo, foi deixada para a semana seguinte. O repórter admitiu, então, que o compositor era um mau regente, "pelo menos para as nossas orquestras", 
dado o desequilíbrio técnico de seus componentes: "Pra reger orquestras assim é preciso ter, além duma grande técnica de regente, a paciência, a habilidade diplomática." Mencionando os vários atritos ocorridos entre músicos e maestro, inclusive a recusa, por parte da orquestra, de executar obra - não mencionada - de autor paulistano, afirmou que a SSSP, que começara "gloriosa" e que o maestro recebeu "em plena pujança", desarranjou-se. Acusou, ainda, a falta de representatividade da música brasileira na temporada do autor carioca pela ausência de Henrique Oswald, Lorenzo Fernandez e Luciano Gallet. ${ }^{8}$

Foi necessário um tempo para que a SSSP se reorganizasse e 1931 iniciou com um convite em tudo honroso para ela: participar das comemorações oficiais na festa da fundação da cidade, a 25 de janeiro. $\mathrm{E}$, apesar da récita não pertencer à programação normal de assinatura, o crítico musical aproveitou o momento para falar de ... política.

"O concerto do Municipal foi, como era de se esperar, admirável. Depois duns meses de hesitação, em que ninguém mais sabia direito que fim havia de levar a Sociedade Sinfônica de São Paulo e a sua orquestra, a Sociedade enfim se reorganizou e já anuncia o seu primeiro concerto da temporada de 1931 pro mês que vem. O sr. Prefeito [Anhaia Melo], lembrando-se de convidar a Sociedade pra comemorar com a sua orquestra o dia mais importante desta nossa boa cidade, mostrou compreender perfeitamente que esta orquestra é o que de mais perfeito já conseguimos como organização coletiva musical de concertos. Não houve, como quiseram alguns interessados insinuar, nenhum engano da parte das Autoridades ao convidar esta Sociedade e não qualquer outra. Isso é uma desculpa pueril de inferiores. E aliás não é possivel confundir esta orquestra e seu regente com nenhuma e nenhum outros, porque em São Paulo eles se colocaram numa superioridade tamanha que não há engano possível. As Autoridades, desejosas mesmo de justiça e de excelência, só podiam convidar pra representar dignamente São Paulo, o que a cidade tem de mais distinto, mais nobre e mais perfeito."

A reorganização deveu-se, sobretudo, à saída do "spalla", Torquato Amore, um dos músicos insubordinados quando da tem- 
porada de Villa-Lobos, substituído por Leonidas Autuori. O exconselheiro da SSSP encontrou a oportunidade para a vingança escrevendo que a orquestra "depurou-se" "dos seus elementos maus" e elogiando a melhora das "condições técnicas" do conjunto. De lambuja, uma sugestão à SSSP para que franqueasse certas apresentações ao povo:

"Um alvitre que não me parece desacertado, seria o de não realizar concertos como o de ontem, por convites. Um concerto com a finalidade do de ontem, devia ser público, e aliás, causava pena ver a quantidade enorme de povo estacionado nas portas do teatro e desejoso de entrar. Por que não se franqueia o teatro ao público, reservando apenas frisas e camarotes de primeira, pro mundo oficial? Assim se faz em Paris, no 14 de julho, na Ópera, na Ópera Cômica, em todos os teatros subvencionados. O público inunda o teatro não há corredor que não esteja repleto, o entusiasmo é delirante, e a manifestação se humaniza duma maneira verdadeiramente comemorativa. É bom exemplo que podíamos seguir, pouco importando, está claro, os que não quisessem tentar a conquista dum lugarzinho, pra não se contaminar de povo. Seria interessante tradicionalizar assim, por meio de grandes concertos francos ao público, o dia mais glorioso desta cidade anchietana, que não fui fundada por Anchieta."

Ainda uma vez cabe adiantar que, como Diretor do Departamento de Cultura, Mário de Andrade abriu as portas do Teatro Municipal para espetáculos gratuitos ou com preços acessíveis à população.

A série de assinatura da SSSP prosseguiu com o $9^{\circ}$ concerto, a 12 de fevereiro, até o $12^{\circ}$, em junho, quando o crítico notificou nova crise, desta vez de ordem financeira. ${ }^{10}$ Pediu claramente providências ao Governo para o amparo da sinfônica a fim de torná-la estável, independente de patronato. $\mathrm{O}$ assunto foi retomado após o $14^{\circ}$ concerto, despedida "dolorosa" da orquestra com a partida de seus melhores integrantes, Lamberto Baldi inclusive, para Montevidéu. ${ }^{11}$ Lançou o último apelo:

"Não é possível que os nosso homens de Governo deixem cair no vazio o apelo que a eles faz a Sociedade Sinfônica de S. 
Paulo. A música mecânica em grande parte inda está isenta de impostos entre nós, o que além de ser milagre espantoso, é também injustiça clamorosa pois que elementos de vida muito mais necessários estão carregados de impostos. E que esse imposto novo venha contribuir pra salvar da morte um foco brilhantíssimo de cultura, um padrão do nosso prazer de sermos paulistas, nada mais justo. É preciso saber esperar sempre."

Houve, de fato, uma tentativa de se amparar a orquestra com a taxação da música mecânica, mas não foi possível saber em que medida isto se deu por sugestão do crítico ou sequer por qual razão a Sociedade não se recompôs. Localizei, no entanto, artigo onde Mário parabenizou o Governo pelo auxílio que pretendia oferecer:

"Sem dúvida o bom acolhimento que os poderes de nosso município deram à idéia de não deixar morrer a Sociedade Sinfônica de S. Paulo, está alegrando todos quantos se interessam realmente pelo progresso musical de $\mathrm{S}$. Paulo. E de fato, seria a mais dolorosa das injustiças que se deixasse a sociedade morrer, tanto mais que os meios descobẹtos para sustentá-la em nada irão pesar nos cofres públicos. A lembrança de taxar a música mecânica, especialmente os rádios, e converter esse arrecadamento de imposto, mínimo para cada um, e importante em conjunto, no sustento duma das mais nobres expressões da cultura paulista, é belíssima. E justíssima também, porque irá beneficiar economicamente aos músicos de orquestra que foram justamente as vítimas do desenvolvimento da música mecânica, que acabou com as orquestrinhas de cinema, e está desprestigiando a assistência aos concertos."

Enfático - "Deus me livre" - frisou não ser contra a música mecânica, concluindo: "(...) a existência duma orquestra quer pra concertos quer pra irradiações faz parte da função socializante dos grandes centros de civilização. O papel destes é arregimentar e fazer progredir as forças civilizadoras, as grandes criações intelectuais duma raça, duma nacionalidade, duma nação." A SSSP merece, enfim, o apoio recebido pela vida que teve, por ter tentado fazer concertos populares, pelos programas, pelo apoio aos compositores brasileiros, "não apenas aos já firmados, como aos que 
ensaiam seus primeiros passos na composição" e pelas numerosas primeiras audições que apresentou, além da "perfeição admirável (e absolutamente excepcional em nosso meio) que conseguiu como apuro orquestral (...)"12

Cabe, agora, retomar a história da Sociedade de Concertos Sinfônicos. De seu quadro de músicos nasceu a orquestra da SSSP e, foi dito, ambas estavam implicadas nas disputas que o jornalista narrou aos leitores do Diário Nacional entre março de 1930 e agosto de 1931, artigos reunidos em "Luta pelo Sinfonismo" e "P.R.A.E.". As vidas das duas associações cruzaram-se com freqüência, na crítica e na política.

É mister esclarecer que, pelos impressos dos programas de música conservados por Mário de Andrade entende-se que, até 1929, antes da fundação da SSSP, sua única fonte de audição para grande conjunto, ao vivo, residia nas apresentações da Sociedade de Concertos Sinfônicos e, eventualmente, da Filarmonia ou da Orquestra do Centro Musical de São Paulo. A SCS, fundada em 1921, era presidida pelo violoncelista Armando Bellardi; dirigida, até 1926, pelo "spalla" Torquato Amore; a partir de janeiro de 1927, passou aos cuidados de Lamberto Baldi. Apresentava-se com regularidade oferecendo, em média, doze récitas anuais mas, em 1929, prenúncio de uma crise, o conjunto exibiu-se apenas três vezes. Armando Bellardi foi expulso pelos professores da orquestra - levando, consigo, o nome da agremiação - e, com a fundação da outra Sociedade, tanto Baldi quanto Amore migraram para o conjunto nascente.

Bellardi, sentindo-se pressionado pelos componentes que permaneceram, arrebanhou uns tantos músicos para um espetáculo usando o mesmo nome, ou seja, Sociedade de Concertos Sinfônicos.

$\mathrm{Na}$ desavença entre os dois grupos, foi dito, Mário de Andrade tomou partido a favor da Sociedade Sinfônica de São Paulo provocando a fúria de Bellardi:

“(...) É preciso ver simples: seria o cúmulo que uma cidade dum milhão de habitantes, não possuísse uma orquestra sinfônica. E seria o cúmulo que perseverássemos em sociedades de 
conventilho, mais ou menos desenvolvido, é verdade, mas sempre conventilho, que nem as que tivemos ultimamente."13

A resposta do maestro italiano, em periódico que não logrei encontrar, exigia defesa rápida, artigo que abriu a série "Luta pelo Sinfonismo": em Decadência, título sugestivo que os leitores do Diário Nacional encontraram a 19 de março de $1930^{14}$, o crítico musical se defendeu, pois fora chamado de "parte interessada" na SSSP. Ofendido, retrucou não fazer parte de tal Diretoria. E, de fato, pelo Capítulo III, Artigo $11^{\circ}$ dos Estatutos da SSSP, a Diretoria era composta só de presidente, vice-presidente, $1^{\circ}$ e $2^{\circ}$ secretários, tesoureiro e Conselho Fiscal. Mário integrou, no entanto, o Conselho Consultivo, cargo ocupado até o $6^{\circ}$ concerto, de 26 de julho de 1930. Ainda cuidadoso - a briga apenas começara - não negava o mérito de uma agremiação tão antiga, acompanhada com assiduidade, mas que "decaiu".

Com a crise sofrida pela SCS em 1929, ficou dificil manter uma agenda regular de apresentações: enquanto ela se exibiu oito vezes, o conjunto rival, de vida efêmera, subiu ao palco, no mesmo período, dezenove vezes. Mas, grupo em fase de reestruturação, a SCS merecia a mesma dedicação do crítico, que aproveitava seu espaço no jornal para incentivar os integrantes, refletir sobre os propósitos de um programa adequado à situação daquela sinfônica, bem como para censurar o "namoro" entre política e arte ${ }^{15}$. Não havendo orquestras cem por cento subvencionadas pelo Governo, as associações musicais recorriam com freqüência aos políticos, buscando-os não apenas como patronos, mas na forma de homenagens. E, já foi visto, o escritor pleiteava, na verdade, o apoio integral à orquestra da SSSP, ou melhor, a sua estabilidade, e não medidas paliativas que a amparassem por um curto espaço de tempo.

Assim, na crítica de 9 de abril de 1930, para o segundo concerto da "nova" SCS, o repórter foi ameno e qualificou como aceitável o que ouvira, tendo em vista as "dificuldades extremas de ordem técnica com que esses músicos tinham a lutar, muitos deles pela primeira vez na vida aparecendo numa orquestra sinfônica (...)". No programa, a Sétima Sinfonia de Beethoven, que a orquestra 
ainda não tinha condições de realizar porque se a "extrema beleza musical" das de números 3, 5 e 6 faziam-nas audíveis mesmo por um conjunto heterogêneo quanto à técnica instrumental dos executantes, as demais exigiam "claridade temática, absoluta nitidez rítmica e absoluta fusão orquestral." Curiosamente, o conjunto se deu bem em Wagner (Siegfried Idill e Prelúdio dos Mestres Cantores), em Henrique Oswald, bem como em Mendelssohn (Fingal's Cave), porque "a Mendelssohn todos os membros executantes desta Sociedade estavam em condições de compreender e realizar." Concluindo, um voto de confiança e estímulo ao regente, Raimundo de Macedo, e mormente à SCS, pois, com exceção dos senões em relação a Beethoven, Mário confessava: "Vibrei, vivi e aplaudi com toda a minha sinceridade."16

O programa do início de maio trouxe aos ouvintes as Valsas Humorísticas de Alberto Nepomuceno, "uma novidade muito importante pra nós", tendo, ao piano, J. Otaviano. Além de não ter gostado da audição, o jornalista irritou-se com a Direção da Sociedade que insistia em apresentar a Sétima Sinfonia de Beethoven: "Raciocinemos com senso-comum: pouco me importa que uma sociedade qualquer execute bem ou mal as obras que apresenta. Agora: quando executa mal, só vou nos concertos dela por obrigação. Se não fosse a obrigação não ia.(... "'17. Acreditando ter deixado clara sua isenção de espírito quando na apresentação anterior elogiara as interpretações de Wagner e Mendelssohn, disse não poder se omitir pois a SCS, pela sua diretoria e condições, insistia em dar dois concertos ao mês. A insistência, para ele, só podia ser atribuída aos interesses financeiros do presidente da SCS.

No espetáculo do dia 18 do mesmo mês, "Em homenagem ao Exmo. Sr. Dr. Júlio Prestes", José Manfredini regeu a Primeira Sinfonia de Beethoven, a la. Suite do Peer Gynt, a abertura Gazza Ladra, de Rossini, trechos do Orfeu, de Gluck, e duas peças de F. Mignone, não nomeadas pelo crítico. No opúsculo distribuído ao público ${ }^{18}$ consta que tenha sido a Dança Austriana (sic) a peça do compositor brasileiro. Desta vez também Mário de Andrade gostou da récita: 
"Esta sociedade arranjou pra sua compreensão estética pessoal uma espécie de montanha-russa interpretativa, que lhe permite ora se elevar em execuções muito boas, ora despencar pro que há de mais infantilmente ruim. Domingo, tivemos um dos concertos, grupo 'bom', da Sociedade." O maestro foi elogiado pela "escolha discreta de programas acessíveis ao conjunto orquestral que dirige e principalmente, nenhum, mas absolutamente nenhum cabotinismo. O sr. Manfredini não dá espetáculo, não é bimbalhante, espinoteante, saltitante, ticoticante ao saudar seu público.(...)" A crítica para a excessiva movimentação de outros chefes de orquestra servia para aqueles que se comportavam com "espetaculosidade de camelô diante do público", mesmo reconhecendo que o bom profissional "tem mesmo um trabalho imenso de movimentação pra tirar de sua orquestra o máximo de vigor e caráter interpretativo", tendo em vista "nosso meio incipiente ainda a respeito de tradição orquestral". ${ }^{19}$

A 5 de agosto o repórter do Diário Nacional curiosamente não mencionou o nome do maestro que regera a SCS na antevéspera, Francisco Mignone, aquele que anos após se tornaria seu grande amigo no Rio de Janeiro. No programa, entre outras obras não citadas, Comala, de Alexandre Levy. E, talvez pelo fato de não ter apreciado o resto do repertório, ou "alma de professor", o intelectual aproveitou o espaço para falar do compositor carioca falecido precocemente, aos 27 anos de idade, "um dos gênios mais promissores da música brasileira". Mas, se de um lado não via em Comala uma obra-prima, achava muito apropriada a inclusão da peça "num repertório sinfônico pro Brasil" por ser "de grande significação histórica pra nós" ${ }^{20}$

Ao que parece o meio musical ainda não superara as brigas do início daquele ano, pois, no final da matéria, Mário observou aos integrantes da orquestra que não fazia questão da simpatia de ninguém: "(..) Mas reflitam numa coisa com sinceridade: quantas vezes os Srs. Professores já ficaram zangados e quantas vezes já ficaram satisfeitos com a minha norma de ação? Várias já. $(\ldots) "$ 
Tal desavença parece explicada, em parte, na crítica para o concerto seguinte, regido por Manfredini, publicada a 4 de outubro. Enquanto o jornalista elogiou o esforço dos músicos, elementos tão díspares, cujo exercício de tocarem juntos fazia a Sociedade progredir mais rápido do que imaginara, lamentou a falta de solistas melhores nos naipes de sopros. Na audição, a já executada Gruta de Fingal, de Mendelssohn, o Concerto para violino, op. 61, de Beethoven - Leonidas Autuori como intérprete - e o Idílio Sentimental da Suite Brasileira de Alexandre Levy, "O que importava mais como música" no espetáculo. E foi por onde o crítico conseguiu elogiar a apresentação de um grupo que estava se "esforçando" para mostrar ao público o A. Levy inédito. ${ }^{21}$

Só no ano seguinte a SCS voltou ao palco, no dia 31 de janeiro, ainda sob a batuta de Manfredini, "um dos estragadores da Rádio Educadora Paulista", e o crítico sentiu-se incomodado para comentar programa tão ruim. Na Quinta Sinfonia de Beethoven, por exemplo, apesar de perceber os esforços dos músicos, acusou a "mediocridade de que os professores de orquestra não têm culpa mas nenhuma." "A culpa toda está na cabeçudice descabelada de diretores sem a mínima responsabilidade. Fiam-se na ignorância e na pachorra públicas. (...)" ${ }^{22} \mathrm{E}$ pior que a interpretação de Beethoven só a do Amor Bruxo, de de Falla, apesar de ser "uma importante primeira audição". Completavam a noite uma "peça nobremente vulgar de Villa-Lobos", não nomeada, e Semiramis, de Rossini. Tempos pós-Revolução, Mário aproveitou o último parágrafo para tratar do namoro entre a política e a arte:

"Mas o que se torna ainda mais indigno, e não é possível mais calar, é a verdadeira... coragem, pra não dizer outra palavra, com que certas Sociedades e músicos de São Paulo, estão agindo pra com as Autoridades constituídas. Na insana busca de proteção, de arranjar dinheiro, perderam toda a discrição, mesmo a mais elementar. Inda está na memória de todos, o dia em que o pobre de Carlos de Campos, tendo subido à presidência, se viu guindado a grande compositor, e executado em todos os concertos. Foi o compositor mais executado do tempo, peças sinfônicas, peças de quar- 
Sociedade de Cultura Artistica

\section{2." Sarau}

THEATRO MUNICIPAL

Sexta-feira, 4 de abril de 1930

ÁS 21 HORAS

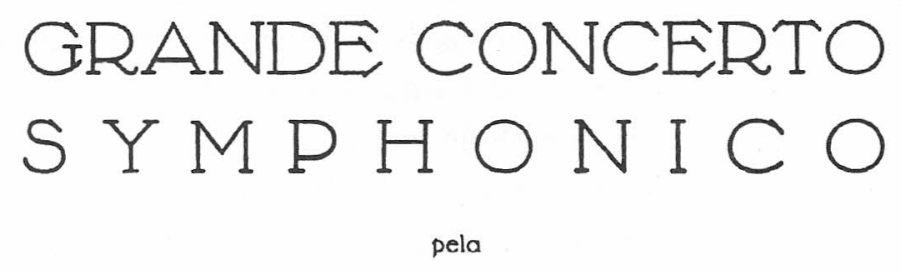

ORCHESTRA DA SOCIEDADE SYMPHONICA DE S. PAULO

sob a direç̧āo do illustre maestro

Lamberto Baldi

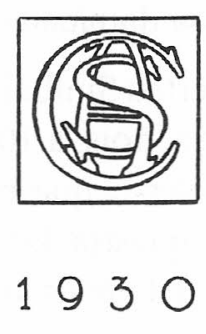

Programa da primeira apresentação oficial da Orquestra Sinfônica do Departamento de Cultura (página central). (Série Programas Musicais Brasileiros, Arq. Mário de Andrade, IEB-USP) 
teto, peças de canto, oh pedras preciosas! não havia pingo musical que não caísse na imaginação paupérrima do sonoro presidente de Estado que os músicos não executassem aqui. Uma coisa vergonhosa. E nem bem o coitado morreu, morreu também pros executantes de S. Paulo, o gênio que a sanha de dinheiro os tinha feito descobrir. Enterraram com o homem que tinham ajudado a meter no ridículo, as pobrezas musicais que ele inventara. Mas não pára nisso a sanha por dinheiro dos nossos músicos. Vamos acabar duma vez com essa história de concertos em homenagem a presidentes de Estado e Interventores. Isso é um rebaixamento moral indecente. Não apenas esta Sociedade de Concertos Sinfônicos, mas todas quantas usam desse gênero de chaleirice, precisam acabar com essa bobagem e serem mais orgulhosas de si. Inda ninguém se esqueceu que esta mesma Sociedade de Concertos Sinfônicos de S. Paulo dedicava o seu concerto de 18 de maio passado 'ao Exmo. Sr. Dr. Júlio Prestes, DD. Presidente Eleito da República', nem bem acabadas as eleições, numa pressa danada de ser a primeira a colher os favores do sultão. E já agora, mal a Sociedade está dando o seu primeiro concerto, depois da Revolução, e o sultão de que namora os favores é outro. Agora é o 'ilustre interventor federal, cel. João Alberto Lins de Barros'. Ora francamente! Vamos morrer de fome, vamos castigar a música nossa até o ponto de constatar-lhe a morte, mas deixemos interventores e presidentes em paz, ficando nós também em paz com a nossa dignidade."

A Sociedade de Concertos Sinfônicos realmente deve ter vestido a carapuça e respondido, pois, a 10 de fevereiro os leitores do Diário Nacional puderam ler o que parece ser uma tréplica do crítico dizendo que se a orquestra foi boa um dia, nada impedia que fosse ora tão ruim. Além do mais, tudo indicava que através de estratagemas políticos Armando Bellardi e José Manfredini teriam levado Lamberto Baldi - considerado, pelo, jornalista, o melhor regente que tivemos e único verdadeiro professor de Composição - a se retirar do meio musical paulistano. Para Mário era patente que, ao adular o meio político Bellardi estava, na verdade, pleiteando subvenção. Lembrando que na semana seguinte não escreveria de- 
vido ao Carnaval, avisou que estava guardando munição para "as considerações que o nosso momento musical está exigindo." 23

Promessa cumprida, a 19 de fevereiro de 1931 o jornalista retomou o assunto tendo sempre em mira a figura de Armando Bellardi. Cabe ressaltar a profissão de fé do crítico confessada a seus leitores, bem como a defesa a Ferreira Prestes, amigo de oficio em outro periódico da capital:

"Por tudo isso o meu caso pessoal não me interessa: o que está curioso é esse estado de ignorância amedrontada, com que certa casta de músicos deficientes como elevação, se vai erguendo contra uma crítica mais profissionalizada e contra os jornais que a procuram sustentar. $\mathrm{O}$ que esses músicos querem é mesmo que se volte àquele estado-precário de reportagem, que só conta as peças que foram bisadas e a gentileza das cantoras. Pois, músicos, felizmente que essa deficiência está passando e a crítica há de ser o que vocês não querem que ela seja, pra descanso de suas malazartes fragílimas. E quanto à competência, só mesmo a ignorância mais chocha, depois da famosa boutade de Schumann e da existência dum Cocteau orientando uma Escola sem ter estudado música, é que preferirá um papagaio que sabe de cor o dó sustenido, ao crítico do 'Diário da Noite' (J.A.F.P.) que não toca violoncelo mas tem cultura musical e é destituido de interesses pessoais." ${ }^{24}$

Apesar das brigas, o dever fez com que Mário comentasse o último concerto da SCS, em fevereiro de 1931. A estréia de Burle Marx regendo em São Paulo não passou desapercebida ao crítico e agradou, embora o jovem maestro estivesse à frente de orquestra muito fraca. Do programa só destacou a inadequação de se apresentar determinado repertório na "doiração" do Teatro Municipal, caso da interpretação do Damúbio Azul pelo maestro carioca. ${ }^{25}$

Abordei, intencionalmente, o repórter do Diário Nacional acompanhando a música sinfônica em São Paulo nos idos de 1930/ 1931. O jornalista não foi imparcial: em tudo acolheu e colaborou com a Sociedade Sinfônica de São Paulo em detrimento da mais antiga, a Sociedade de Concertos Sinfônicos. Uma análise reducionista, simplista e falsificadora apontaria o favorecimento 
daquela que era presidida pela amiga, D. Olivia Guedes Penteado, enquanto a outra tinha à frente o implicante Armando Bellardi. Poderia, no entanto, ter acompanhado a crítica de Mário de Andrade para a música de câmara e chegaria ao mesmo ponto. Ou seja, fazendo um jornalismo "de combate" - em sintonia com o momento político que vivia e a postura do jornal para o qual trabalhava ele observava, analisava, criticava e propunha soluções de forma construtiva. Assim, e é o ponto que quero ressaltar, o intelectual amadureceu a proposta para um grupo sinfônico que pudesse trabalhar de forma ideal, aí compreendendo-se: escolha de repertório, agenda de espetáculos, estabilidade de emprego para os músicos, formação de público, incentivo a jovens maestros e compositores.

A Revolução de 32, no entanto, calou o jornalista não apenas por ter fechado o Diário Nacional. Mais que isso, o desânimo se apossou de tal forma de sua pena que, meses depois, em maio de 1933, estreando à frente de outro periódico, ele se mostrou um crítico apático e condescendente:

"Dos dias de junho do ano passado, em que fiz as minhas últimas notas de crítica de arte no Dićrio Nacional, até o dia de hoje, em que retomo o ofício neste Diário de S. Paulo, não medeiam nem doze meses. No entanto, me sinto bem outro, e talvez já agora a minha escrita não possua aquele dom tristonho de irritar a muita gente, que tinha dantes. Não sei, uma espécie de velhice fatigada me prende agora a vontade de falar. Se é certo que já muito exerci aquela modorrenta filosofia da paciência, tão própria do nosso povo, agora me entrego tenebrosamente à filosofia do não-vale-a-pena, enquanto discursam aos ares os árduos heliotropos revolucionários. Será mesmo velhice? ... Embora a velhice de idade não esteja de fato excessivamente afastada dos meus quarenta anos de complacência o meu estado atual de não-vale-a-pena derive duma velhice mais especial, digamos 'heliotrópica"'.26

E reitero que escolhi acompanhar a vida das duas orquestras que disputaram espaço em São Paulo naquele momento porque foi no convívio com a orquestra da SSSP que o intelectual aprendeu como organizar, ou melhor, como estruturar o funcionamento de 
um conjunto sinfônico em seus mínimos detalhes, compra de instrumentos e montagem do impresso distribuído ao público, inclusive. Paralelamente, observando a reestruturação da SCS pôde idear qual seria o repertório para um conjunto com dificuldades técnicas ou em via de formação.

Atendendo aos convites de Fábio Prado e Paulo Duarte para dirigir o Departamento de Cultura, Mário de Andrade acumulou uma segunda chefia, a da Divisão de Expansão Cultural. Formada pela Discoteca Pública e Seções de Teatro e Cinemas e de Rádio Escola, contava com a eficiência de Oneyda Alvarenga e Paulo Magalhães, respectivamente, uma vez que a Rádio Escola não chegou a funcionar.

Da parceria com Paulo Magalhães resultou o traçado das linhas gerais de trabalho do Trio São Paulo, Quarteto Haydn, Coral Paulistano, Madrigal e Orquestra Sinfônica, todos recém-fundados, cujos objetivos podem ser resumidos, grosso modo, na formação da coletividade de intérpretes e de ouvintes. Os grupos instrumentais menores foram os primeiros a se estruturar. A orquestra só passou a figurar da programação oficial em 1936, no " 1 Concerto Público" de 28 de março, sob a regência de Ernst Mehlich. A metrópole contava agora com grupos estáveis e era necessário pensar em suas atividades a pequeno, médio e longo prazos. Logo, cabia estimular compositores e maestros, bem como propor uma programação variada para público novo e antigo, os "habitués" do Teatro.

Foram justamente os "habitués" - ouvintes assíduos - os grãfinos que freqüentavam a sala em recitais e temporadas caríssimas, os primeiros a reclamar das alterações que iam sendo conduzidas, pois, temiam até que a franquia do Municipal aos trabalhadores pudesse vir a danificar o prédio. ${ }^{27}$

$\mathrm{O}$ ritmo das realizações era tão impressionante que, em doze meses de trabalho, de maio de 1935 a maio de 1936, já tinham sido criados, só na esfera da música instrumental, os concursos para uma obra sinfônica, um quarteto de cordas e uma suíte para banda. Com o início do funcionamento da Orquestra também foi inaugu- 
rada a série de incentivo aos compositores brasileiros jovens. Para a primeira noite, a dança Batucajé, de Francisco Mignone, figurando ao lado das obras de Beethoven, Rossini, Schubert e Weinberger. No folheto, o texto não assinado, do próprio Diretor do Departamento, apresenta a "novidade":

"Trata-se duma orquestra moderna, diferente da antiga, porque os tempos mudaram, mas igualmente equilibrada e rica. Os seus efeitos chocam apenas os que ainda não estão acostumados a ouvir música moderna, e a isto o público paulista precisa se acostumar. Só é verdadeiramente feliz o povo que, sem desprezar o passado, saiba amar e entender o tempo em que vive. Erra quem imagina que o passado foi melhor que o presente. E seria uma feia injustiça que não entendêssemos nem cultivássemos os grandes artistas da atualidade, em nome de um passado que, por ilustre que seja, não poderá mais voltar. Se já compreendemos o passado, busquemos compreender também o presente, porque assim, além de termos mais numerosos prazeres artísticos, distribuiremos os nossos aplausos com justiça mais honesta."

Mignone inaugurou, também, a série dedicada a novos maestros, série esta que, segundo o Diretor do Departamento, assumia excepcional importância na música paulista por ser a regência "uma arte bem dificil". O maestro e pianista radicado no Rio de Janeiro regeu, além de duas peças de sua autoria, Bellini (abertura da Nor$m a$ ), Albeniz-Mignone (Asturias) e Carlos Gomes (abertura de $O$ Guarani).

Durante seu primeiro ano de existência a Orquestra Sinfônica justificou plenamente sua criação apresentando-se inúmeras vezes em noites patrocinadas não apenas pelo Município, mas encabeçadas pela Sociedade de Cultura Artística, extremamente ativa, e participando da montagem das catorze óperas da Temporada Lírica Oficial. Na programação do Departamento de Cultura a agremiação nova ensaiava sob as batutas de Camargo Guarnieri, Francisco Murino, Nicolino Milano, Ernst Mehlich ou Francisco Casabona executando Ottorino Respighi, Silvio Motto, Artur Pereira, Frutuoso Viana, Debussy, Wagner, Mendelssohn, Rossini e Mozart, 
mescla de primeiras audições, nomes novos e obras consagradas em repertórios dirigidos à educação e mera fruição do público.

A comunidade ganhava um outro presente, em abril de 1936, anunciado na página central do programa do dia 27: "Piano do Teatro Municipal". As casas locadoras, como Manon ou Sotero, deixaram de lucrar duplamente: na locação do instrumento, bem como no "merchandising" dos opúsculos onde se liam os agradecimentos a estas lojas. Não era a única alteração que o público percebia nos impressos já que Mário de Andrade contratara artistas plásticos de renome para ilustrarem as capas, belas ilustrações, traços arrojados, assinados por Yokanaan, Nelson Nóbrega, Oswald Andrade Filho, Vitorio Gobbis, Quirino Campofiorito, Tarsila do Amaral e Anita Malfatti, entre outros.

O balanço, ainda que sumário, da programação da orquestra do Departamento de Cultura durante o ano de 1936 mostra que, de fato, a metrópole poderia contar, a partir de então, não apenas com livretos bem cuidados, repertórios diversificados, calendário regular de espetáculos e franquia a concertos. De maior significado para a história da cidade contava-se, a partir da gestão de Mário de Andrade, com um grupo sinfônico estável o que, para os músicos, representava, no mínimo, o cessar da "insana busca de proteção".

O crítico e professor de música que tanto se empenhara pela existência de uma sinfônica pôde acompanhar os três primeiros anos de seu funcionamento. Em 1938, desiludido com a política e os políticos, mudou-se para o Rio de Janeiro aceitando convite de Gustavo Capanema para lecionar na Universidade do Distrito Federal e trabalhar no Instituto Nacional do Livro. Foi durante sua estadia na Capital que estreitou a amizade com Francisco Mignone.

Como se sabe, da parceria Mário de Andrade-Francisco Mignone surgiria, anos mais tarde, o poema Café, libreto para uma ópera. Mas, em data ignorada, certamente anterior a 1942, ambos partilharam um outro sonho: a criação de uma Orquestra Sinfônica Brasileira vinculada ao então Ministério da Educação e Saúde. Num "Memorandum", sete folhas manuscritas com o detalhamento da verba necessária, quadros de músicos e funcionários, orçamentos, 
etc., o compositor submeteu seu belo e ambicioso projeto à experiência do amigo. Conhecedor do desencanto de Mário de Andrade, bem como de sua determinação em não se meter mais com política, Mignone escreveu à página seis:

"O Sr. M. de A. não apresentará o presente projecto. Toma a responsabilidade do mesmo o Sr. F. Mignone. Depois... depois será o que a Liddy cantar a viva voz!"28

Não cabe, aqui, investigar o paradeiro do projeto carioca. Cabe, sim, ressaltar que a criação de uma Orquestra Sinfônica, em São Paulo, alterou de forma decisiva o rumo da história da música da metrópole.

\section{NOTAS}

1. Série Programas Musicais Brasileiros, exemplar n 207, Arquivo Mário de Andrade, Instituto de Estudos Brasileiros - Universidade de São Paulo. (Cf. Catálogo da Série por Flávia Camargo Toni)

2. ANDRADE, Mário de. Empresa Scotto. Série Recortes, Pasta R. 35, Arquivo Mário de Andrade, IEB-USP. (Cf. Catálogo da Série por Vera Lúcia G. Bertagna)

3. IDEM. In: Música, doce Música, 2. ed. p. 185.

4. IDEM. Sociedade Sinfônica de S. Paulo. Série Recortes, Pasta R. 35, Arquivo Mário de Andrade, IEB-USP. (Artigo de 29 jan. 1930)

5. IDEM. In: Música, doce Música, 2. ed. p. 227.

6. IDEM. Ibidem, p. 146.

7. IDEM. Ibidem, p. 149.

8. IDEM. Ibidem, p. $153-164$.

9. IDEM. Músicas do Dia de São Paulo. Série Recortes, Pasta R. 35, Arquivo Mário de Andrade, IEB-USP. (Artigo de 27 jan. 1931)

10. IDEM. In: Música, doce Música, 2. ed., p. 243.

11. IDEM. Ibidem, p. 244.

12. IDEM. Sociedade Sinfônica de S. Paulo. Série Recortes, Pasta R. 35, Arquivo Mário de Andrade, IEB-USP. (Artigo de 27 ago. 1931)

13. IDEM. Esperança. Ibidem. (Artigo de 29 jan. 1930)

14, IDEM. In: Música, doce Música. 2. ed., p. 219.

15. As críticas de sete das oito apresentações da Sociedade de Concertos Sinfônicos, após a crise de 1929, figuram em "Luta pelo Sinfonismo", $\mathrm{n}^{\circ} \mathrm{s}$ I, III, IV, VI, VII, VIII e XII. A oitava, de 18 de maio de 1930, permaneceu inédita.

16. IDEM. Música, doce Música, 2. ed. p. 223. 
17. IDEM. Ibidem, p. 225.

18. Série Programas Musicais Brasileiros, Arquivo Mário de Andrade, IEB - USP. (exemplar $n^{\circ} 143$ )

19. ANDRADE, M. de. Sociedade de Concertos Sinfônicos. Série Recortes, Pasta R. 35, Arquivo Mário de Andrade, IEB - USP. (Artigo de 20 maio 1930)

20. IDEM. In: Música, doce Música, 2. cd., p. 228.

21. IDEM. Ibidem, p. 230.

22. IDEM. Ibidem, p. 232.

23. IDEM. Ibidem, p. 234.

24. IDEM. Ibidem, p. 236.

25. IDEM. Ibidem, p. 241.

26. In: ANDRADE, M. de. Música e Jornalismo: Diário de S. Paulo; pesquisa, estabelecimento do texto, introdução e notas de P. Castagna. São Paulo, Edusp/Hucitec, 1993, p. xv. (Ricardo Cipicchia, artigo de maio de 1933)

27. DUARTE, Paulo. Mário de Andrade por ele mesmo. 2. ed. São Paulo, Hucitec/SCCT, 1977. p. 35

28. MIGNONE, Francisco. Memorandum. In: ANDRADE, M. de. Fichário Analítico, Série Manuscritos de Mário de Andrade, Arquivo Mário de Andrade, IEB-USP. (Seção Música/Generalidades, ficha Orquestra Sinfônica) (Cf. Catálogo da Série por Vera Lúcia Natale)

Liddy Chiafarelli, pianista, esposa de Francisco Mignone e, como ele, grande amiga de Mário de Andrade. 